\title{
Studies on benthic communities of rocky shores on the Brazilian coast and climate change monitoring: status of knowledge and challenges
}

\author{
Ricardo Coutinho ${ }^{1}$, Luciana Erika Yaginuma ${ }^{1}$, Fernanda Siviero ${ }^{1}$, Julio César Q. P. dos Santos ${ }^{1}$, \\ María Soledad López ${ }^{2}$, Ronaldo Adriano Christofoletti, Flávio Berchez ${ }^{4}$, Natalia Pirani Ghilardi- \\ Lopes $^{5}$, Carlos Eduardo Leite Ferreira ${ }^{6}$, José Eduardo Arruda Gonçalves ${ }^{1}$, Bruno Pereira Masi ${ }^{1}$, \\ Monica Dorigo Correia ${ }^{6 \dagger}$, Hilda Helena Sovierzoski ${ }^{7}$, Luis Felipe Skinner ${ }^{8}$, Ilana Rosental Zalmon ${ }^{9}$ \\ ${ }^{1}$ Instituto de Estudos do Mar Almirante Paulo Moreira (IEAPM). \\ (Rua Kioto 253, Arraial do Cabo, RJ, Brazil, 28930-000) \\ ${ }^{2}$ Centro de Biologia Marinha, Centro de Biologia Marinha. \\ (Rod. Manoel Hipólito do Rego km 131,5 - Praia do Cabelo Gordo - 11600000 - São Sebastião, SP - Brazil) \\ ${ }^{3}$ Instituto do Mar, Universidade Federal de São Paulo. \\ (Av. Alm. Saldanha da Gama 89, Ponta da Praia, Santos, SP, CEP: 11030-400, Brazil) \\ ${ }^{4}$ Universidade Federal de Santa Catarina Departamento de Botânica, Centro de Ciências Biológicas \\ (CEP:88040-970, Florianópolis, SC, Brasil) \\ ${ }^{5}$ UFABC - Universidade Federal do ABC. \\ (Av. dos Estados, 5001. Bairro Bangu. Santo André - SP - Brasil . CEP 09210-580) \\ ${ }^{6}$ Universidade Federal Fluminense, Centro de Estudos Gerais, Departamento de Biologia Marinha. \\ (Campus do Valonguinho Centro 24001970 - Niterói, RJ - Brasil) \\ ${ }^{7}$ Universidade Federal de Alagoas, Departamento de Biodiversidade e Ecologia. Setor de Comunidades Bentônicas(LABMAR/ICBS). \\ (Rua Aristeu de Andrade, $452-2^{\circ}$ andar, Farol, Maceió, Alagoas, Brasil, CEP: 57021-090) \\ ${ }^{8}$ Universidade do Estado do Rio de Janeiro, Departamento de Ciências. \\ (Rua Francisco Portela, 1470 - Patronato 24435000 - São Gonçalo, RJ - Brasil) \\ ${ }^{9}$ Universidade Estadual do Norte Fluminense Darcy Ribeiro, Laboratório de Ciências Ambientais, Laboratório de Ciências Ambientais. \\ (Av. Alberto Lamego 2000 - Horto CENTRO 28013-602 - Campos dos Goytacazes, RJ - Brasil \\ *Corresponding author: rcoutinhosa@yahoo.com \\ Financial Support: ReBentos
}

\section{ABSTRACT}

A rocky shores working group (WG) integrated with ReBentos (Monitoring Network for Coastal Benthic Habitats; Rede de Monitoramento de Habitats Bentônicos Costeiros) was created and linked to the Coastal Zones Sub Network of the Climate Network (MCT; Sub-Rede Zonas Costeiras da Rede Clima) and to the National Institute of Science and Technology for Climate Change (INCT-MC; Instituto Nacional de Ciência e Tecnologia para Mudanças Climáticas), to study the vulnerability of benthic communities on rocky shores and the effects of environmental changes on biomes in such environments along the Brazilian coast. The synthesis presented here was one of the products of this GT, and aimed to collect and review existing knowledge on benthic communities present on rocky shores of the Brazilian coast, their associated biodiversity, and the potential of future studies to accurately predict/measure the effects of climate change on such environments and their biota.

Descriptors: Synthesis, Benthic communities, Rocky shores, Brazilian coast, Climate change.

\section{RESUMO}

Um grupo de trabalho de costões rochosos (GT) integrado à ReBentos (Rede de Monitoramento de Habitats Bentônicos Costeiros), e vinculado à Sub-Rede Zonas Costeiras da Rede Clima (MCT) e ao Instituto Nacional de Ciência e Tecnologia para Mudanças Climáticas (INCT-MC), foi criado para estudar a vulnerabilidade das comunidades bentônicas dos costões rochosos e os efeitos das alterações ambientais sobre a respectiva biota. A presente síntese foi um dos produtos desse GT e teve como objetivo principal levantar e revisar o conhecimento existente sobre as comunidades bentônicas de costões rochosos na costa brasileira, a biodiversidade associada, e verificar as potencialidades de estudos futuros para uma previsão/mensuração mais acurada dos efeitos das mudanças climáticas sobre os ambientes e sua biota.

Descritores: Síntese, Comunidade bêntica, Costão rochoso, Costa brasileira, Mudanças climáticas. 


\section{INTRODUCTION}

\section{DEFINITIONAND MAINCHARACTERISTICSOF ROCKY SHORES}

Rocky shores are a transitional ecosystem between land and marine environments, and, together with other benthic coastal habitats, are among the most productive marine environments on the planet. Rocky shores are composed mainly by marine organisms and the biota on the intertidal region, and the challenges is posed by both seawater and air exposures because they are at the boundary between marine and terrestrial environment. Therefore, these organisms and communities are likely indicator systems of the impacts of climate change.

Rocky shores are common intertidal environments in coastal areas throughout the world formed by solid rocks, forming different habitats as steep rocky cliffs, platforms, rock pools and boulder fields. In the Brazilian coast, there are two different rocky shore formations. The first are true rocky shores formed by rock structures extending from the ocean floor to few meters above sea level, which are mostly found in the southeast and on islands. The second, in the north and northeast regions, are clusters of rock fragments formed by boulder that may hold species characteristic of rocky shores (GUILARDI et al., 2008).

Rocky shores are dynamic environments under the influence of a wide variety of biotic and abiotic drivers. As a result, a high richness of species of ecological and economic importance, such as mussels, oysters, crustaceans and a diversity of algae and associated fish (LITTLER; LITTLER, 2000) develop in this environment. A high biomass and primary production of microphytobenthons and macroalgae is found due to the input of large quantities of nutrients from terrestrial systems. Consequently, rocky shores are feeding, growth and reproduction sites for many species of consumers (COUTINHO; ZALMON, 2009). The great diversity of species on rocky shores and the availability of substrate as a fundamental resource for sessile organisms increases biological interactions, the strength of which is mediated by environmental factors (ex. hydrodynamics, temperature, tides, etc.) (GUILARDI et al., 2008).

The integration of the environmental drivers (wave exposure, emersion time) and the biological interactions (e.g. competition, predation) influences the pattern of distribution of organisms at small spatial scales. As a result, organisms are distributed at different vertical levels according to their tolerance to dissecation and dominance ranges, establishing worldwide zonation patterns (STEPHENSON; STEPHENSON, 1949).
In the Brazilian coast, an overall pattern of distribution and dominance of organisms is found with some regional differences depending on local characteristics. In general, the infralitoral fringe (zone between the lowest tide during spring and neap phases) is dominated by a wide variety of macroalgae with presence of Sabelariid reefs of the genus Phragmatopoma spp, mussels Perna perna and barnacles Megabalanus coccopoma, while the midlitoral zone (between the lowest neap tide and the high tide level) is dominated by the barnacles Tetraclita stalactifera (at low midlitoral) and Chthamalus bisinuatus (at high midlitoral), mussels Brachidontes spp and biofilm. Consumers are found over these zones in different dominance mainly by limpets (infralitoral fringe and midlitoral), periwinkles (supralitoral), whelks and sea urchins (infralitoral fringe) (see COUTINHO; ZALMON, 2009; CHRISTOFOLETTI et al., 2010, 2011a,b).

The dominant organisms in this region are functionally similar around the world, which facilitates the standardization of initiatives monitoring in different parts of the world. Secondary effects of global climatic changes such as increases in water and air temperature, sea level variations and reduction in water $\mathrm{pH}$ may also affect the diversity, distribution and abundance of rocky shore organisms. Increases in temperature and sea level and the reduction of water $\mathrm{pH}$ are examples of global changes that may lead to substantial changes in the diversity, distribution and abundance of species on rocky shores. Understanding such shifts depends on an intense and sustained effort of ecological monitoring combined with field and laboratory experiments.

In the intertidal, the organisms are subject to air exposure once or twice a day at low tide due to the diurnal or semi-diurnal tidal regime. Periods of spring tides are the most critical for these organisms as the time of exposure reaches the maximum. In this moment, organisms may face temperatures above $50^{\circ} \mathrm{C}$ and endure a temperature range of $30^{\circ} \mathrm{C}$ in a single day depending on the water temperature at high tide (as observed in Arraial do Cabo, RJ), the season, latitude, time of day, low tide, and where the organisms are located. Therefore, many resident organisms are considered to be at their physiological tolerance limit, and any changes in abiotic parameters related to climate change, such as water or air temperature, or the air exposure time, may lead to negative events such as mortality or even local extinction (HELMUTH, 2002, 2009). 
To study the vulnerability of benthic communities on rocky shores, and the effects of environmental changes on biomes in such environments along the Brazilian coast, a rocky shores working group (WG) integrated with ReBentos (Monitoring Network for Coastal Benthic Habitats; Rede de Monitoramento de Habitats Bentônicos Costeiros), was created and linked to the Coastal Zones Subnetwork of the Climate Network(MCT; Sub-Rede Zonas Costeiras da Rede Clima), and to the National Institute of Science and Technology for Climate Change (INCT-MC; Instituto Nacional de Ciência e Tecnologia para Mudanças Climáticas). The WG aimed to consolidate a research network, through an extensive methodological discussion among researchers from different regions of the country, and began a time series to obtain standardized data that enable continued monitoring of these environments.

Thus, the main goal of this study is to collect and review existing knowledge on benthic communities present on rocky shores, their biodiversity, and the potential of future studies to accurately predict/measure the effects of climate change on such environments and their biota. The study was divided into three main parts: 1) Environment, comprising definition and main features, location along the coast, ecosystem/environmental services rendered and the main local threats; 2) Survey of the existing knowledge; and 3) Effects of climatic changes.

\section{GEOGRAPHICAL DISTRIBUTION OF HABITAT ON THE} COAST

Diversity on rocky shores throughout the Brazilian coast is the result of a complex interaction between biogeographic and historical factors. Such factors include the characteristics of the water bodies (particularly of the Northern and Southern currents of Brazil), of the Falkland currents, and of the outcrops located in the South Atlantic Central Water (SACW); hard substrate availability and the presence of large freshwater systems and biotic interactions. OLIVEIRA (1998) demonstrates that the Amazon and La Plata Rivers are the primary determining factors of the phycofloristic features of our coast. These two large rivers function as insurmountable barriers for many species of benthic marine organisms due to the high volume of fresh water and sediment supplied to the marine environment (OLIVEIRA, 1998). Apparently, some species abundant in the Caribbean and absent from Brazil have reached the Caribbean from the Indo-Pacific, whereas the Amazon River already drains a considerable amount of water into the Atlantic. This pattern would generally explain the biogeographical differences between the marine biota along the northeast coast of Brazil and that of Venezuela and Colombia. Nevertheless, it is not clear what possible influence (or not) the African coast may have on the composition of Brazilian flora and fauna. Some of the common species observed in both coast may be related to the age of the barriers, the actual currents that reach the northeastern coast from Bengala Currents, or transportation by ships which seems to be the case of Mitilidae Perna perna, which is abundant in the Brazilian southeastern coast and South African coast, and apparently arrived came by ships slaves (FERNANDES et al., 2008).

At the southern end, the La Plata River plays the same biogeographical role by blocking species of temperate affinity, which occur on the Argentine coast, from invading (at least seasonally) the southern and southeastern coast of Brazil.

We can divide the Brazilian coastal zone into three main areas concerning the presence of rocky shores based on the distribution of benthic organisms:

1. One zone ranges from Amapá to the north of Bahia, and is characterized by a coast of unconsolidated sediment or hard sediment, formed mainly of sandstone reef ecosystems, and encrusted by coralline algae, sponges, corals, bryozoans and several other groups of benthic invertebrates. The reef ecosystem occur mainly from the coast of Rio Grande do Norte state until the mouth of the São Francisco River (southern Alagoas border), extending approximately $600 \mathrm{~km}$. The reef ecosystems are composed of coral or biogenic reefs, and of sandstone reefs located in the offshore zone and near the coastline, where the upper reef platform is exposed during low tide and with benthic organisms typical of intertidal regions. The small rock formation present near Cabo de Santo Agostinho (Cape of Saint Augustine; Pernambuco coast), and other rocky formations along the north and northeast coast, formed mainly by boulders (some large) are exceptions.

2. This zone comprises the coastal area from north of Bahia, where crystalline outcrops forming rocky shores are common, to the south of the island of Santa Catarina, characterized by large bedrock availability on the continental edge, and cut by numerous bays and coves, as well as in small beaches separated by rocky spurs, and numerous islands and islets. The deep-water upwelling arising from the SACW occurs within this zone. The main point of upwelling occurs in the region of Cabo Frio (RJ) (CARBONEL, 2003). 
The last region extends from the southern area of Santa Catarina to the Torres region (RS), and is characterized by extensive sandy beaches, and rare crystalline outcrops on the mainland and islands.

In addition, we find oceanic islands such as Fernando de Noronha, São Pedro and São Paulo, Trindade and Martim Vaz, that also present extensive rocky shores.

In this biogegraphical context, the most extensive rocky shores are present, almost exclusively, on the southern and southeastern coast of Brazil. The main characteristic of the Southeast is the proximity of Serra do Mar, which in many places directly reaches the sea. The sudden inflexion of the orientation of the coast, and of the isobathymetric to the west (near Cabo Frio), due to the Rio de Janeiro fracture zone caused the structural alignments of the crystalline basement (northeast-southwest direction), to become shortened by the approximately east-west orientation of the coast between Cabo Frio and the Bay of Angra dos Reis. Thus, we can consider that the main stretch of the Brazilian coast with rocky shores ranges from Espírito Santo to Torres, the last hard natural substrate in the state of Rio Grande do Sul. The species composition has subtropical characteristics, and a high diversity of species in this region, except for the area influenced by the Cabo Frio upwelling. The benthic fauna and flora of the area influenced by the Cabo Frio upwelling has elements with temperate and tropical affinities. This region acts as a biogeographical barrier for a large number of species.

\section{SURVEY OF EXISTING KNOWLEDGE}

A total of 327 scientific papers from 1944 to 2014 were used to synthesize studies on rocky shores along the Brazilian coast(Figure 1 and Appendix 1: http://www.io.usp. br/index.php/arquivos/send/337-vol-64-special-issue-22016/3992-annex-1015). These studies were grouped into articles published in journals, thesis or dissertations, books or chapters, and proceedings. In this survey, reef ecosystems were also counted for a separate summary work because in many situations, these ecosystems are located neighboring rocky shores. In addition, it was also important to compare rocky shore ecosystems with reef ecosystems to assess the research efforts already undertaken in these ecosystems.

The studies conducted from 2000 to 2014 were classified by type of study defined as follow (Figure 2):

Biodiversity - studies on more than one floral or faunal species, or on a group of organisms.

Observational - descriptive studies emphasizing ecological aspects.

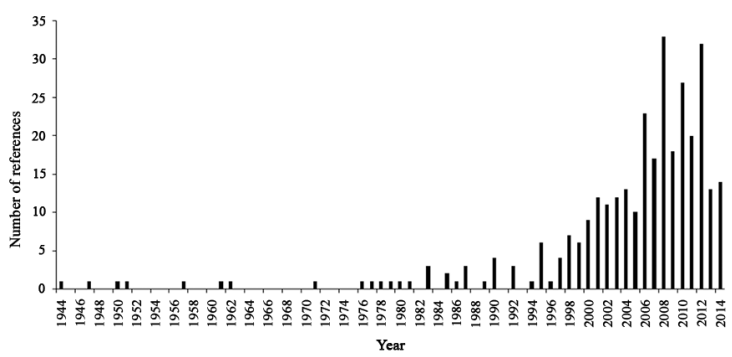

Figure 1. Number of references on rocky shores and coral reef ecosystems, per year.

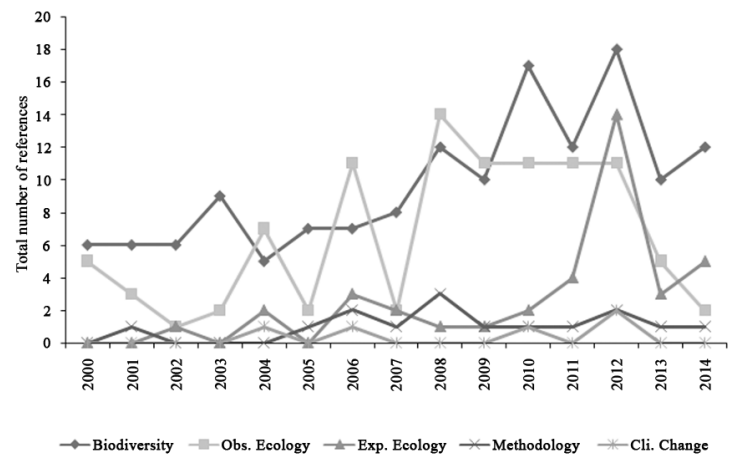

Figure 2. Total number of references on benthic communities per type of study, from 2000 to 2014 .

Experimental - studies that involve some type of sample or experimental design in the field or controlled laboratory conditions, used to answer questions or test scientific hypotheses.

Methodological - Studies with emphasis on the establishment of field sampling or experimental methods.

Climate changes: Studies relating climatic aspects to benthic organisms.

Although they began in the 40s, studies on rocky shores in Brazil experienced a boost in the 80s (Figure 1), mainly including floral and faunal surveys. A high variability in the number of observational ecological studies over time, and an increase in the number of experimental ecological studies from the year 2010 are apparent. It is also important to note that biodiversity, observational, and (recently) experimental studies have prevailed on the Brazilian coast. Studies related to climate change have been minimal, showing the urgent need to implement this type of study (Figure 2).

The substrate type used was also identified in the survey. A good portion of the studies focused on rocky shores and coral reefs. However, studies on sandstone reefs and boulders were observed in locations such as northern and northeastern Brazil, where true "rocky shores" are virtually inexistent (Figure 3). 


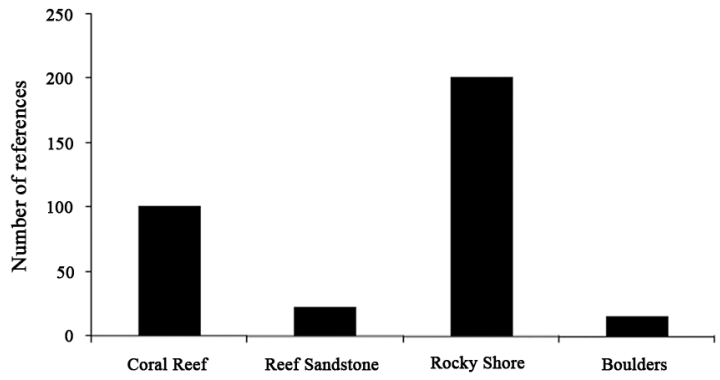

Figure 3. Number of references on rocky shores and reef ecosystems from 1944 to 2014 grouped by type of substrate.

The survey also showed that much of the information available in the literature is located in scientific papers (Figure 4). However, nearly $20 \%$ of the studies available are thesis, dissertations and conference proceedings. This percentage is likely to increase over the coming years due to the adoption of extended abstracts by national conferences of the field such as the Brazilian Congress of Zoology (Congresso Brasileiro de Zoologia), Brazilian Congress of Oceanography (Congresso Brasileiro de Oceanografia) and Brazilian Congress of Marine Biology (Congresso Brasileiro de Biologia Marinha).

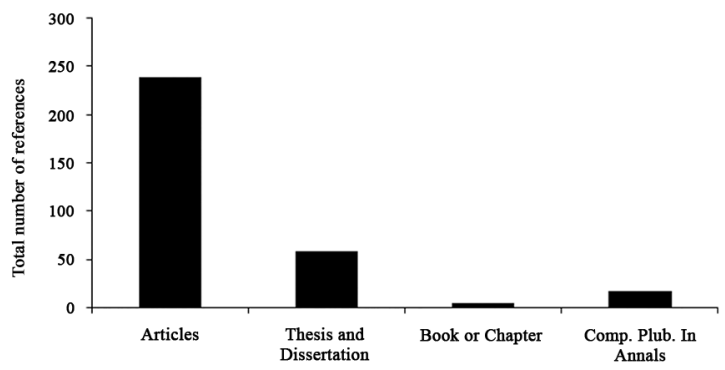

Figure 4. Number of references on rocky shores and reef ecosystems, per type of publication.

Most studies on rocky shores in Brazil were concentrated in the southeast, which may be explained by the larger number of rocky shores in this region, and by the existence of more researchers in Rio and São Paulo (Figure 5). We may also observe a large number of studies in the State of Bahia due to the Abrolhos Park, which has been the target of numerous studies carried out by Brazilian and foreign scientists.

\section{MAIN LOCAL THREATS BEYOND THE CLIMATIC CHANGES}

The exploitation of species of economic interest, the introduction of exotic species, waste, land speculation, pollution and over fishing are prominent among the

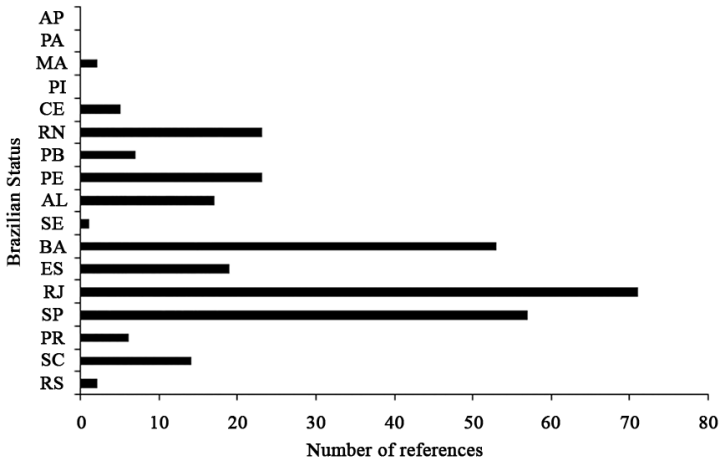

Figure 5. Number of references on rocky shores and reef ecosystems per Brazilian state.

factors that exert pressure on the biological diversity of rocky shores.

The mussel Perna perna Linnaeus, 1758, is one of the main sessile species captured on the rocky shores of the southeastern region of the Brazilian coast, and can be collected at a young age to be used as seed for aquaculture systems, or as adults for food. The effect of intensive mussel extraction has not been evaluated, however it certainly changes the entire community structure in places where mussels are dominant. Fauna associated with the mussel are also simultaneously removed, changing the structure of those communities and of other benthic organisms.

The introduction of some exotic species, whether voluntary or controlled (such as the oyster Crassostea gigas Thumberg, 1793), may benefit the local economy. The oyster, introduced in the 70 s for cultivation in Arraial do Cabo, RJ, does not yet have a record of breeding under natural conditions in the region, as a certain threshold of low temperature is required for gonad maturation. The oyster is currently widely cultivated on the coast of Santa Catarina and has a great economic importance for the region. On the other hand, the arrival of exotic species from the hulls of ships, oil platforms and other floating artificial structures are serious problems for the native fauna. The most recent case has been the spread of sun corals (species Tubastrea coccinea and $T$. taguesensis) on the Brazilian coast (CREED et al., 2008). This organism grows significantly in artificial and rocky substrates in the southeast, especially in the region of Ilha Grande, RJ, and it poses a potential risk to the local community biodiversity. Alternative measures to control sun coral are needed to contain the coral in other areas of the Brazilian coast, as there are already records of this species on the northeast (BA, AL) and southeast (SP, PR and SC) coasts (COUTINHO et al., 2013). 
Garbage on the rocky shores may compromise population development, especially in the intertidal zone because garbage, among other potential impacts, may reduce water circulation and create shade for algae. However, the mentioned effects require evaluations to be replicated at broad temporal and spatial scales.

Building of ports, buildings, factories, and real estate expansion in regions near urban areas, are the main anthropogenic pressures on rocky shores. The building of houses, among others, due to privatization of rocky shores is a major problem for the organisms of this ecosystem. The insertion of areas with artificial hard substrate from large construction projects on the north coast of the state of Rio de Janeiro (e.g., Açu port) has been observed, creating a link where previously there was no hard substrate. In addition, the release of, often in natura, sewage impairs the growth of many benthic species.

Pollution from industrial effluent may lead to a reduction of species or even change the reproductive processes of benthic organisms. For example, the presence of heavy metals, TBT, and other compounds may directly affect the ratio of males and females in gastropod populations, causing changes in the reproductive organs called imposex. Populations of gastropod predators inhabiting rocky shores near port regions, such as Thais (=Stramonita) and Leucozonia, exhibit the imposex process, generating a much higher proportion of males over females due to the presence of TBT in the water (LIMAVERDE et al., 2007)

Overfishing carried out by diving in the subtidal region of rocky shores is one of the main environmental impacts affecting the structure of benthic populations. The removal of top predators in the food chain can increase the abundance of herbivorous fish, reducing algal coverage. Rocky shores are used by fishing and extractivist communities, which rely on them for survival in sparsely populated regions, where these ecosystems service the communities.

Tourism and increases in coastal area population (whether for housing or vacation) have intensified problems in the southeast. The privatization of beaches to build condominiums, for example, has become more severe in the past years, especially in the southeast, despite being illegal in the Brazilian constitution. Such condominiums lead to several environmental issues that will contribute to the degradation of rocky shore ecosystems. In addition, recreational tourism using motorboats directly affects the communities present on rocky shores with oil spills and docking in reef areas.
Rocky shores, in turn, do not have a legally defined status for public recognition as a proper or defined ecosystem when compared to other environments such as reefs or mangroves. Consequently, public policies established for the preservation of rocky shores are defined within a broader context of other ecosystems, and thus, such shores lack their own identity. Therefore, there is little awareness, regarding the different impacts that rocky shores are subject, to making them hostage to unplanned development. Rio das Ostras, RJ, where a municipal law establishes protection of rocky shores in the county (known as Natural Monument of Rocky Shores), is an exception to the rule.

In this context, rocky shores are essential ecosystems for conservation and to decrease the vulnerability of coastal regions. The potential effect of biodiversity loss, as the species of ecological and economical importance, on ecosystem functioning and the services provided to society is troubling. It is important to consider how significantly rocky shore biodiversity can help in maintaining the stability of coastal ecosystems. Natural systems considered stable are more reliable at providing environmental services.

Scenarios of the expected climatic changes indicate an increase in physical stress (e.g., storms). Local anthropogenic impacts resulting from the multiple uses of coastal regions may cause the loss of some key species in ecosystems. It is unclear how these different impacts may affect ecosystem processes and, consequently, environmental services.

\section{EFFECTS OF CLIMATE CHANGE ON ROCKY SHORES AND THEIR BIODIVERSITY}

Increases in surface water temperature and sea level, changes in salinity and in hydrodynamics related to exposure to waves, undertow and ocean circulation are among the impacts of global climate change predicted for marine ecosystems. Furthermore, a decrease in seawater $\mathrm{pH}$ is expected because of the increased $\mathrm{CO}_{2}$ concentration in the atmosphere (NICHOLLS et al., 2007). Little has been produced on climate change research in Brazil, but understanding the knowledge from other areas in the world, and the start of a monitoring approach in the Brazilian coast will help to better understand the vulnerability and the impacts for this region.

Coastal ecosystems are among the most vulnerable to the changes caused by climate change, especially the intertidal areas, which have shown faster biogeographic 
changes (BARRY et al., 1995; HELMUTH et al., 2006) than those found in terrestrial environments (ROOT et al., 2003). Long-term monitoring studies have shown that the distribution limits of the intertidal biota of hard substrates have progressed toward the poles at a rate of over $50 \mathrm{~km}$ per decade (RICKETS, 1985; SOUTHWARD et al., 1995; HELMUTH et al., 2006), and highlight how this action is urgent in a large and diverse coast as found in Brazil.

Invertebrates and seaweeds, inhabiting intertidal habitats may, be particularly vulnerable to fluctuating temperatures, as individuals must adapt to the extreme temperatures of both the terrestrial and marine environments (FIELDS et al., 1993). A range of thermal conditions are found at small spatial scales in the intertidal zone, and they may exceed the range of large latitudinal bands. Therefore, the inhabiting organisms are believed to be at the limit of their physiological tolerance and any changes in abiotic parameters (e.g., temperature and air exposure time) could lead to death, local extinction (HELMUTH, 1999; HELMUTH, 2002; MASSA et al., 2009) or to the expansion of the range and distribution area. Thus, intertidal areas are potential environments to assess the effects of climate change (HELMUTH, 2009). In this context, it is important to consider that rocky shores in the Brazilian coast go from tropical zone to subtropics, thus, changes in temperature can lead to a changes in the range of distribution for many species in these boundaries. For instance, increasing in temperature can expand the southern limit of many species from the region of SP/ $\mathrm{PR} / \mathrm{SC}$ towards the south.

The passage of cold fronts is a natural and unpredictable weather disturbance, where the associated winds generate high-energy waves able to disturb benthic communities, and play an important role in structuring local communities. The south and southeast coast in Brazil are particularly affected by the influence of cold fronts from the South, where the dynamics of oceanoclimatic processes and the benthic-pelagic links are influenced at different temporal scales (MAZZUCO et al., 2015). These extreme events may arise as a result of climate change, affecting the structure and functioning of benthic communities of the intertidal zone. The influence of waves/undertow/storms on rocky shores has been addressed considering changes in community species composition, species richness and diversity, the intensity of interactions such as competition and predation, and even the expansion of the zone occupied by organisms, and the respective bands. Such changes are reflected in the "patch" dynamics of organisms (see review in COUTINHO; ZALMON, 2009). Studies seeking to understand the effects of climate-mediated disturbances (e.g., storms and weather fronts) on benthic assemblages at temporal and regional scales and in coastal areas have been conducted worldwide (POSEY et al., 1996; UNDERWOOD, 1999; WILLIAMS; ROSE, 2001; AAGAARD et al., 2005; HOUSER; GREENWOOD, 2007). However, the consequences of climate change in the mid-medium and long term on community structure should be carefully evaluated given the scarcity of large time series data on the Brazilian coast.

Local monitoring is required to determine the factors that definitively influence the occurrence of each organism (DENNY et al., 2004), as differences are often not explained in terms of absolute data. Air temperature, for example, is not the temperature experienced by organisms on the rocky shore, which is formed by several components that often are not considered in the final analysis of the measured temperature. These organisms are doubly subject to possible climate change for being exposed to two environment fluctuations, terrestrial and marine. Increased rain frequency changes salinity, adversely affecting the traits of different groups such as mortality rate, release of larvae, and others (SIMPSON; HURLBERT, 1998; CHAN et al., 2001; BRAVO, 2003; RESGALLA et al., 2007). The combination of factors must also be considered. An organism may adapt to an environmental variation when exposed to only one. If more than one factor is modified (e.g., salinity and $\mathrm{pH}$ ), the physiological pressure may be intolerable for the organism (PRZESLAWSKI et al., 2005; VERWEEN et al., 2007; RESGALLA JUNIOR et al., 2007).

Long-term time series are important for understanding the functioning of this ecosystem, an environment that undergoes natural seasonal community changes, with some sessile organisms expanding or retracting their occupation in the bands and other organisms appearing at a certain time of year covering the entire range or completely disappearing at a different time (e.g., several species of the genus Ulva). Long-term time series help to assess how natural oceanographic events, such as the North Atlantic Oscillation (NAO), and more specifically to the southern hemisphere, the El Niño Southern Oscillation (ENSO), affect species distribution gradients. Time series analysis (wavelet) showed that relationships between recruitment 
and environmental indexes are more consistent annually, but multi-year periodicity is also important (MENGE et al. 2011). Thus, conducting studies that link large-scale measurements to local scale measurements is important to compare and predict changes resulting from human activity.

In summary, global changes comprise complex changes. However, these complex changes have direct indicators such as air and sea temperature, oxygen availability, salinity and $\mathrm{pH}$, abiotic variables that greatly influence the biology of all species. Physiological stresses resulting from changes in the afore mentioned variables and from extreme events such as cold fronts/undertow may cause large biogeographical changes and affect the habitat distribution mosaic (SOMERO, 2012).

Despite the wide coastline and the presence of different climate regions that are potentially influenced by climate change effects, these effects on rocky shore communities are still poorly studied in Brazil. Initiating studies that address this topic is urgent. The simplified protocol developed by the rocky shores of ReBentos WG (COUTINHO et al., 2015) aims to encourage the engagement of groups working in this environment to obtain long-term time series on community changes. In addition, organism-level studies are critical to understanding the ability to adapt to climate change.

Finally, testing scientific hypotheses is important to facilitate the unification of studies related to monitoring the influence of climate change on rocky shores; for example, i) if hydrodynamics and average sea level variations will induce changes in the zonation pattern (such as, changing organism colonization sites in regards to the current locations, or enlargement/reduction of dominance bands); ii) if changes in undertow frequency and intensity will promote more frequent physical disorder in benthic ecosystems, and cause the pulling out and/or fragmentation of organisms (especially in the intertidal area), shifting species composition and abundance; iii) if changes in precipitation will change the input of freshwater and sediment into the sea, and the evaporation rate, which in turn will affect variables such as salinity and sea water transparency, creating unfavorable conditions for stenobiont species, and inducing changes in species composition and abundance; and iv) if changes in temperature and sea water acidification, will influence the metabolism of sessile organisms (especially the perennial), affecting growth, reproduction and survival rate, and inducing shifts in species composition and abundance.

\section{REFERENCES}

AAGAARD, T.; KROON, A.; ANDERSEN, S.; SØRENSEN, R. M.; QUARTEL, S.; VINTHER, N. Intertidal beach change during storm conditions; Egmond, The Netherlands. Marine geology. v. 218, n. 1, p. 65-80, 2005.

BARRY, J. P.; BAXTER, C. H.; SAGARIN, R. D.; GILMAN, S. E. Climate-related, long-term faunal changes in a California rocky intertidal community. Science, v. 267, n. 5198, p. 672-675, 1995.

BRAVO, S. Sea lice in Chilean salmon farms. Bull. Eur. Assoc. Fish Pat., v. 23, p. 197-200, 2003.

CARBONEL, C. A. A. L. Modelling of upwelling-downwelling cycles caused by variable wind in a very sensitive coastal system. Cont. Shelf Res., v. 23, n. 16, p. 1559-1578, 2003.

CHAN, B. K. K.; MORRITT, D.; WILLIAMS, G. A. The effect of salinity and recruitment on the distribution of Tetraclita squamosa and Tetraclita japonica (Cirripedia; Balanomorpha) in Hong Kong. Mar. Biol., v. 138, n. 5, p. 999-1009, 2001.

COUTINHO, R.; GONÇALVES, J. E. A.; DE MESSANO, L. V. R.; FERREIRA, C. E. L. Avaliação crítica das bioinvasões por bioincrustação. A Ressurgência, v. 7, p. 11-18, 2013.

COUTINHO, R.; ZALMON, I. R. Os Bentos de costões rochosos. In: PEREIRA, R. C.; SOARES-GOMES, A. (Eds.). Biologia Marinha. Rio de Janeiro: Interciência, 2009. p. 281-298.

COUTINHO, R.; SZÉCHY, M. T. M.; LÓPEZ, M. S.; CHRISTOFOLETTI, R. A.; BERCHEZ, F.; YAGINUMA, L. E.; ROCHA, R. M.; SIVIERO, F. N.; GHILARDI-LOPES, N. P.; FERREIRA, C. E. L.; GONÇALVES, J. E. A.; MASI, B. P.; CORREIA, M. D.; SOVIERZOSKI, H. H.; SKINNER, L. F.; ZALMON, I. R. Monitoramento de longo prazo de costões rochosos. In: TURRA, A.; DENADAI, M. R. Protocolos para o Monitoramento de Habitats Bentônicos Costeiros - Rede de Monitoramento de Habitats Bentônicos Costeiros - ReBentos. (Org.). São Paulo: Instituto Oceanográfico da Universidade de São Paulo, 2015. 258 p.

CREED, J. C.; OLIVEIRA, A. E. S.; DE PAULA, A. F. Cnidaria, Scleractinia, Tubastraea coccinea Lesson, 1829 and Tubastraea tagusensis Wells, 1982: Distribution extension. Checklist, v. 4, n. 3, p. 297-300, 2008.

CHRISTOFOLETTI, R. A., MURAKAMI, V. A., OLIVEIRA, D. N., BARRETO, R. E. \& FLORES, A. A. V. Foraging by the omnivorous crab Pachygrapsus transversus affects the structure of assemblages on sub-tropical rocky shores. Mar. Ecol. Prog. Ser., v. 420, p. 125-135, 2010.

CHRISTOFOLETTI, R. A.; TAKAHASHI, C. K.; OLIVEIRA, D. N.; FLORES, A. A.V. Abundance of sedentary consumers and sessile organisms along the wave exposure gradient of subtropical rocky shores of the south-west Atlantic. J. Mar. Biol. Assoc. U. K., v. 91, n. 5, p. 961-967, 2011 a.

CHRISTOFOLETTI, R. A.; ALMEIDA, T. V. V.; CIOTTI, A. M. Environmental and grazing influence on spatial variability of intertidal biofilm on subtropical rocky shores. Mar. Ecol. Prog. Ser., v. 424, p. 15-23, 2011 b.

DENNY, M.; HELMUTH, B.; LEONARD, G. H.; HARLEY, C. D. G.; HUNT, L. J. H.; NELSON, E. K. Quantifying scale in ecology: lessons from a wave-swept shore. Ecol. Monogr., v. 74, n. 3, p. 513-532, 2004.

FERNANDES, F. C.; SOUZA, R. C. C. L.; JUNQUEIRA, A. O.; RAPAGNÃ, L.; RAMOS, A. B. Distribuição Mundial e o Impacto da sua Distribuição no Brasil. In: RESGALLA JÚNIOR, C.; WEBER, I. W.; CONCEIÇÃO, M. B. (Eds.). O mexilhão Perna perna (L.). Rio de Janeiro: Interciência, 2008. p. 25-30. 
FIELDS, P. A.; GRAHAM, J. B.; ROSENBLATT, R. H.; SOMERO, G. N. Effects of expected global climate change on marine faunas. Trends Ecol. Evol., v. 8, n. 10, p. 361-367, 1993.

GUILARDI, N. P.; PEREIRA FILHO, G. H.; BERCHEZ, F. Current knowledge status on the ecology of hard bottom benthic communities in Brazil and the need for new approaches. Oecol. Bras., v. 12, n. 2, p. 197-205, 2008.

HELMUTH, B. From cells to coastlines: how can we use physiology to forecast the impacts of climate change? J. Exp. Mar. Biol. Ecol., v. 212, n. PT 6, p. 753-760, 2009.

HELMUTH, B. How do we measure the environment? Linking intertidal thermal physiology and ecology through biophysics. Integr. Comp. Biol., v. 42, n. 4, p. 837-845, 2002.

HELMUTH, B. Thermal biology of rocky intertidal mussels: quantifying body temperatures using climatological data. Ecology, v. 80 , n. 1 , p. $15-34,1999$.

HELMUTH, B.; MIESZKOWSKA, N.; MOORE, P. J.; HAWKINS, S. J. Living on the edge of two changing worlds: forecasting the responses of rocky intertidal ecosystems to climate change. Annu. Rev. Ecol. Evol. Syst., v. 37, n. 1, p. 373-404, 2006.

HOUSER, C.; GREENWOOD, B. Onshore migration of a swash bar during a storm. J. Coast. Res., v. 23, n. 1, p. 1-14, 2007.

LIMAVERDE, A. M.; WAGENER, A. L. R.; FERNANDEZ, M. A.; COUTINHO, R. Stramonita haemastoma as a Bioindicator for organotin contamination in tropical coastal environments. Mar. Environ. Res., v. 64, n. 3, p. 384-398, 2007

LITTLER, D. S.; LITTLER, M. M. Caribbean reef plants: an identification guide to the reef plants of the Caribbean, Bahamas, Florida and Gulf of Mexico. Washington: Offshore Graphics, 2000. 542 p.

MASSA, S. I.; ARNAUD-HAOND, S.; PEARSON, G. A.; SERRÃO, E. A. Temperature tolerance and survival of intertidal populations of the seagrass Zostera noltii (Hornemann) in Southern Europe (Ria Formosa, Portugal). Hydrobiologia, v. 619, n. 1, p. 195-201, 2009.

MAZZUCO, A. C. A.; CHRISTOFOLETTI, R. A.; PINEDA, J.; STARCZAK, V. R.; CIOTTI, A. M. Temporal variation in intertidal community recruitment and its relationships to physical forcings, chlorophyll-a concentration and sea surface temperature. Mar. Biol., v. 162, n. 9, p. 1705-1725, 2015.

MENGE, B. A.; GOUHIER, T. C.; FREIDENBURG, T.; LUBCHENCO, J. Linking long-term, large-scale climatic and environmental variability to patterns of marine invertebrate recruitment: Toward explaining "unexplained" variation. J. Exp. Mar. Biol. Ecol., v. 400, n. 1/2, p. 236-249, 2011.

NICHOLLS, R. J.; WONG, P. P.; BURKETT, V. R.; CODIGNOTTO, J. O.; HAY, J. E.; MCLEAN, R. F.; RAGOONADEN, S.; WOODROFFE, C. D. Coastal systems and low-lying areas. Chapter 6 in Climate Change 2007: Impacts, Adaptation and Vulnerability. In: PARRY, M.; CANZIANI, O. F.; PALUTIKOF, J. P.; VAN DER LINDEN, P.; HANSON, C. E. (Eds.).
Contribution of Working Group II to the Fourth Assessment Report of the Intergovernmental Panel on Climate Change. Cambridge: Cambridge University Press, 2007. Available: < http://www.ipcc.ch/pdf/assessment-report/ar4/wg2/ar4-wg2-chapter6.pdf>

OLIVEIRA, E. C. The seaweeds resources of Brazil. In: CRITCHLEY, A.; OHNO, M. (Eds). Seaweeds of the world. Yokosuka: JICA, 1998. p. 366-371.

POSEY, M.; LINDBERG, W.; ALPHIN, T.; VOSE, F. Influence of storm disturbance on an offshore benthic community. Bull. Mar. Sci., 59, n. 3, p. 523-529, 1996.

PRZESLAWSKI, R.; DAVIS, A. R.; BENKENDORFF, K. Synergistic effects associated with climate change and the development of rocky shore molluscs. Glob. Change Biol., v. 11, n. 3, p. 515-522, 2005.

RESGALLA JÚNIOR, C.; BRASIL, E. D. S.; SALOMÃO, L. C. The effect of temperature and salinity on the physiological rates of the mussel Perna perna (Linnaeus 1758). Braz. Arch. Biol. Technol., v. 50, n. 3, p. 543-556, 2007.

RICKETTS, E. F.; CALVIN, J.; HEDGEPETH, J. W.; PHILLIPS, D. W. Between pacific tides. Stanford: Stanford University Press, 1985.

ROOT, T. L.; PRICE, J. T.; SCHNEIDER, S. H.; ROSENZWEIG, C.; POUNDS, J. A. Fingerprints of global warming on wild animals and plants. Nature, v. 421, n. 6918, p. 57-60, 2003.

SCHEFFER, M. Ecology of Shallow Lakes. Berlin: Springer, 2004.

SIMPSON, E. P.; HURLBERT, S. H. Salinity effects on the growth, mortality and shell strength of Balanus amphitrite from the Salton Sea, California. Hydrobiologia, v. 381, n. 1, p. $179-190,1998$.

SOMERO, G. N. The physiology of global change: linking patterns to mechanisms. Ann. Rev. Mar. Sci., v. 4, p. 39-61, 2012.

SOUTHWARD, A. J.; HAWKINS, S. J.; BURROWS, M. T. Seventy years observations of changes in distribution and abundance of zooplankton and intertidal organisms in the western English Channel in relation to rising sea temperature. J. Therm. Biol., v. 20, n. 1/2, p. 127-155, 1995.

STEPHENSON, T. A.; STEPHENSON, A. The Universal feature of zonation between tide-marks on rocky coasts. J. Ecol., v. 37, n. 2, p. 289-305, 1949.

UNDERWOOD, A. J. Physical disturbances and their direct effect on an indirect effect: responses of an intertidal assemblage to a severe storm. J. Exp. Mar. Biol. Ecol., v. 232, n. 1, p. 125140,1999

VERWEEN, A.; VINCX, M.; DEGRAER, S. The effect of temperature and salinity on the survival of Mytilopsis leucophaeata larvae (Mollusca, Bivalvia): The search for environmental limits. J. Exp. Mar. Biol. Ecol., v. 348, n. 1/2, p. 111-120, 2007.

WILLIAMS, J. J.; ROSE, C. P. Measured and predicted rates of sediment transport in storm conditions. Mar. Geol., v. 179, n. 1/2, p. 121-133, 2001. 
